\title{
Cleavage beyond the block stage and survival after transfer of early bovine embryos cultured with trophoblastic vesicles
}

\author{
Sylvaine Camous, Y. Heyman, Wided Méziou and Y. Ménézo*
}

Station Centrale de Physiologie Animale, Institut National de la Recherche Agronomique, 78350 Jouy-en-Josas, and ${ }^{*}$ Laboratoire de Biologie 406, Institut National des Sciences Appliquées, 69621 Villeurbanne Cédex, France

\begin{abstract}
Summary. Early bovine embryos (1- to 8-cell stages) were recovered from superovulated heifers at slaughter on Days 2 or 3. Embryos were cultured for 3-4 days in Medium B2 supplemented with $15 \%(\mathrm{v} / \mathrm{v})$ fetal calf serum in the absence (B2SS, 106 embryos) or presence of trophoblastic vesicles (B2SS + TV, 190 embryos).

At the end of culture, there were more $(P<0.001)$ morulae $(\geqslant 16$ cells) in B2SS $\times$ TV $(46 \%)$ than in B2SS alone $(18 \%)$ irrespective of the initial cell stage. More 8 -cell embryos reached the 16-cell stage than did embryos with $<8$ cells $(30 \%$ vs $15 \%$ in B2SS, $P>0.05 ; 70 \%$ vs $41 \%$ in B2SS + TV, $P<0.005$ ). After culture, 102 morulae were transferred non-surgically to temporary recipient heifers ( 84 embryos cultured in B2SS + TV and 18 in B2SS). After 2 or 3 days, 14 out of 58 embryos from the B2SS + TV group and 3 out of 10 embryos from the B2SS group were recovered as blastocysts. Most blastocysts were deep-frozen and stored for several weeks. After thawing, 10 apparently normal embryos from the B2SS + TV group were transferred non-surgically into 10 recipient heifers. Four pregnancies were induced, but only one embryo survived to term (birth of a normal male calf).

It is concluded that trophoblastic vesicles release one or several unknown compound(s) normally present in vivo, promoting the cleavage of early bovine embryos.
\end{abstract}

\section{Introduction}

Despite the effort of a number of workers using a variety of culture media and conditions, the success rate for the in-vitro culture of early bovine embryos (1- to 8-cell stages) to blastocysts has generally been low, whereas older embryos (morulae) can be readily grown to blastocysts (reviewed by Wright \& Bondioli, 1981). The most successful report, although based on small numbers of embryos, used a medium formulated from the composition of oviduct fluid and a low oxygen tension (Tervit, Whittingham \& Rowson, 1972). The development of most early bovine embryos was arrested at the 8-12-cell stage, termed the "critical stage" or "block stage" by Thibault (1966). Such a block may be similar to that observed in the mouse, in which eggs of outbred strains are blocked at the 2-cell stage in vitro unless they are transferred back into oviducts in organ culture (Whittingham \& Biggers, 1967). Muggleton-Harris, Whittingham \& Wilson (1982) showed that the cleavage arrest can be overcome by injecting cytoplasmic compounds from embryos of mouse strains that do not exhibit this in-vitro block.

On the basis of these results, we have tried to establish whether fragments of bovine embryos recovered beyond the block stage were able to transmit compounds via the culture medium to early bovine embryos, and thereby promote further cleavage in vitro. We have recently described a procedure for obtaining trophoblastic vesicles ('embryos' without an embryonic disc) derived from Day-14 bovine embryos and have shown that this tissue is able to develop in vitro for at least 5 days 
and maintains some of its physiological activity (e.g. luteolysis inhibition) after transfer (Heyman, Camous, Fèvre, Méziou \& Martal, 1984).

In this study, the effect of trophoblastic vesicles on the in-vitro development of early bovine embryos was determined by using a co-culture system. The viability of such co-cultured embryos was examined by transferring them to recipient heifers. Part of this work has been reported in abstract form (Camous, Heyman \& Ménézo, 1984).

\section{Materials and Methods}

Embryo donor animals

Pure-bred and cross-bred Charolais heifers were used as donors. They were induced to superovulate with twice daily intramuscular injections of pituitary extracts (FSH-P, Burns-Biotec, Omaha, NE, U.S.A.) given in decreasing doses for 5 days starting on Day 9-13 of the cycle (Elsden, Nelson \& Seidel, 1978). Luteolysis was induced by $750 \mu \mathrm{g}$ cloprostenol (Estrumate: ICI-Pharma, Reims, France) injected $72 \mathrm{~h}$ after the start of FSH treatment. The females were artificially inseminated with a single dose of frozen semen from the same bull 48 and $60 \mathrm{~h}$ after the injection of cloprostenol.

\section{Embryo recovery}

Embryos at early stages of cleavage. Embryos at the 1-8-cell stages were recovered from superovulated heifers on Days 2, 2.5 and 3 (Day $0=$ onset of oestrus). Within 10 min after slaughter each oviduct was flushed with Medium B2 (Api-System, la Balme les Grottes, Montalieu-Vercieu, France) (Ménézo, 1976) at $\mathrm{pH} 7.6$ and $37^{\circ} \mathrm{C}$. If all the embryos (in relation to the number of ovulations) were not recovered, the uterine horns were also perfused. The embryos were kept at $38^{\circ} \mathrm{C}$ in Medium B2 under an atmosphere of $5 \% \mathrm{CO}_{2}, 5 \% \mathrm{O}_{2}, 90 \% \mathrm{~N}_{2}$ until culture.

Preparation of bovine trophoblastic vesicles. Embryos were collected non-surgically from superovulated heifers on Days 13 and 14, using phosphate-buffered saline solution (PBS: Tervit et al., 1972 ) enriched with $0.2 \%(w / v)$ bovine serum albumin (Fraction V powder: Sigma, St Louis, MO, U.S.A.). From these embryos, $0 \cdot 3-13 \mathrm{~mm}$ long, trophoblastic vesicles were prepared by the method described by Heyman et al. (1984). Each fragment of tissue was cultured for at least $24 \mathrm{~h}$ at $38^{\circ} \mathrm{C}$ in an atmosphere of $5 \% \mathrm{CO}_{2}, 20 \% \mathrm{O}_{2}, 75 \% \mathrm{~N}_{2}$ before being used in co-culture with early embryos. After $24 \mathrm{~h}$ in suspension in the medium, these fragments of mainly trophoblastic tissue became spherical or oblong, ranging between 0.4 and $4 \mathrm{~mm}$ diameter according to the size of the initial piece.

\section{In-vitro culture}

Early embryos were cultured for 3 or 4 days in Medium B2 supplemented with $15 \%$ fetal calf serum (v/v) in plastic 4-well culture plates (Nunclon Delta: Poly Labo, Paul Block \& Cie, Strasbourg-Meinau, France) at $38^{\circ} \mathrm{C}$ under a humidified atmosphere of $5 \% \mathrm{CO}_{2}, 5 \% \mathrm{O}_{2}, 90 \% \mathrm{~N}_{2}$. The fetal calf serum (FCS) was prepared in this laboratory from four 8-month-old bovine fetuses and was heated at $56^{\circ} \mathrm{C}$ for $30 \mathrm{~min}$ before use. Embryos (1-3) at the same cell stage were assigned to one of the two culture systems: in $0.3 \mathrm{ml}$ Medium B2 supplemented with FCS (B2SS, control group) or in 0.3-1 ml Medium B2 (according to the size of the vesicle) supplemented with FCS and containing one trophoblastic vesicle (B2SS + TV, experimental group). Embryo development was evaluated by morphological observation under an inverted microscope at $24-\mathrm{h}$ intervals. At the end of culture, the attainment of at least the 16-cell stage was used as the criterion of cleavage beyond the block stage. Treatment differences were evaluated by $\chi^{2}$ analysis. 


\section{Transfer of cultured embryos}

The viability of cultured embryos that had reached the 16-cell stage during culture was assessed by development for 2-3 days in the uterus of temporary recipient heifers. The oestrous cycles of the recipient heifers were synchronized with 2 injections of $500 \mu \mathrm{g}$ cloprostenol administered intramuscularly 11 days apart and the embryos were transferred on Day 6 of the cycle. The embryos (in groups of $1-15$ ) originating from the same initial cell stage and cultured under identical conditions were placed into a French straw with $0.2 \mathrm{ml}$ Medium B2 and then transferred via the cervix with a Cassou gun (Instruments de Médecine Vétérinaire, L'Aigle, France) (Renard, Heyman \& du Mesnil du Buisson, 1977) into the middle third of the uterine horn ipsilateral to the corpus luteum. After 2 or 3 days, the embryos were collected non-surgically (Ozil, Heyman \& Cassou, 1980); at this stage they would normally be expected to be blastocysts. Most embryos recovered at the blastocyst stage were deep-frozen by the method described by Renard, Heyman \& Ozil (1982) and stored for 2-26 weeks. After thawing, morphologically normal embryos were transferred non-surgically into the uterine horn ipsilateral to the corpus luteum of a recipient on Day 8 of the cycle. Each recipient was checked twice daily for oestrus and an early pregnancy diagnosis was performed using assay of plasma progesterone on Day 21. Pregnancy was confirmed by rectal palpation during Days 60-90.

\section{Histological analysis of cultured embryos}

Some embryos reaching the 16-cell stage in vitro and some blastocysts cultured for 3 days and recovered after 2 days in vivo were fixed in $2 \%$ glutaraldehyde in $0 \cdot 15 \mathrm{M}$-cacodylate buffer, $\mathrm{pH} 7 \cdot 3$, then in $1 \% \mathrm{OsO}_{4}$ in the same buffer of $1 \mathrm{~h}$ each, dehydrated in ethanol and embedded in Epon. Semi-thin sections $(0.5 \mu \mathrm{m})$ were stained with toluidine blue.

\section{Results}

Development of early embryos in vitro

A greater proportion of embryos developed into morulae ( $\geqslant 16$ cells) in co-culture with trophoblastic vesicles than when cultured alone $(46 \%$ compared with $18 \% ; P<0.001)$. This improved development observed irrespective of the initial cell stage was only significant at the 1-, 2- and 8-cell stages (Table 1). However, 8-cell embryos exhibited a higher percentage development into morulae than did 1- to 4-cell embryos whatever the culture system (30\% compared with $15 \%$ in Medium B2SS, $P>0.05 ; 70 \%$ compared with $41 \%$ in Medium B2SS + TV, $P<0.005$ ). Some of the 8-cell embryos reached the compact morula stage. The extent of development of the embryos in both systems is presented in Text-fig. 1. The distributions of the cell stages were significantly different between the two culture systems except for the 4-cell stage $(P<0.005$ for 1 - and 2-cell embryos;

Table 1. Effect of the presence of trophoblastic vesicles (TV) on the development in vitro of 1 - to 8 -cell bovine embryos into morulae ( $\geqslant 16$ cells)

\begin{tabular}{ccccc}
\hline $\begin{array}{c}\text { Initial stage } \\
\text { of development }\end{array}$ & $\begin{array}{c}\text { No. of } \\
\text { embryos }\end{array}$ & $\begin{array}{c}\text { Co-culture } \\
\text { with TV }(+)\end{array}$ & $\begin{array}{c}\text { Length of } \\
\text { culture (days) }\end{array}$ & $\begin{array}{c}\text { No. of embryos } \\
\text { developing into } \\
\text { morulae (\%) }\end{array}$ \\
\hline 1-cell & 55 & + & 4 & $23(42)^{* *}$ \\
& 49 & - & 4 & $9(18)$ \\
2-cell & 80 & + & 3 or 4 & $30(38)^{* *}$ \\
& 25 & - & 3 or 4 & $2(8)$ \\
4-cell & 22 & + & 3 & $11(50)$ \\
& 12 & - & 3 & $2(17)$ \\
8-cell & 33 & + & 3 & $23(70)^{* *}$ \\
& 20 & - & 3 & $6(30)$ \\
\hline
\end{tabular}

Values compared with corresponding control group: ${ }^{* *} P<0.01$ ( $\chi^{2}$ analysis). 
$P<0.025$ for 8-cell embryos). After culture in Medium B2SS, $\simeq 50 \%$ of the embryos of each initial cell stage showed arrested development at the 8 -cell stage ( $47 \%$ of the 1 -cell embryos and $56 \%$ of the 2 -cell embryos) or at the 9-15-cell stage ( $50 \%$ of the 4 - and 8-cell embryos), while only $20-30 \%$ of the embryos cultured in Medium B2SS + TV remained at the corresponding cleavage stage $(22 \%$, $27 \%, 32 \%$ and $21 \%$ of the 1-, 2-, 4- and 8-cell embryos, respectively). After culture in Medium B2SS + TV, most embryos had reached the morula stage ( $\geqslant 16$ cells) irrespective of the initial cell stage, whereas in Medium B2SS most embryos were at the 8-cell or 9-15-cell stage when the initial cell stages were 1 and 2 cells or 4 and 8 cells, respectively.

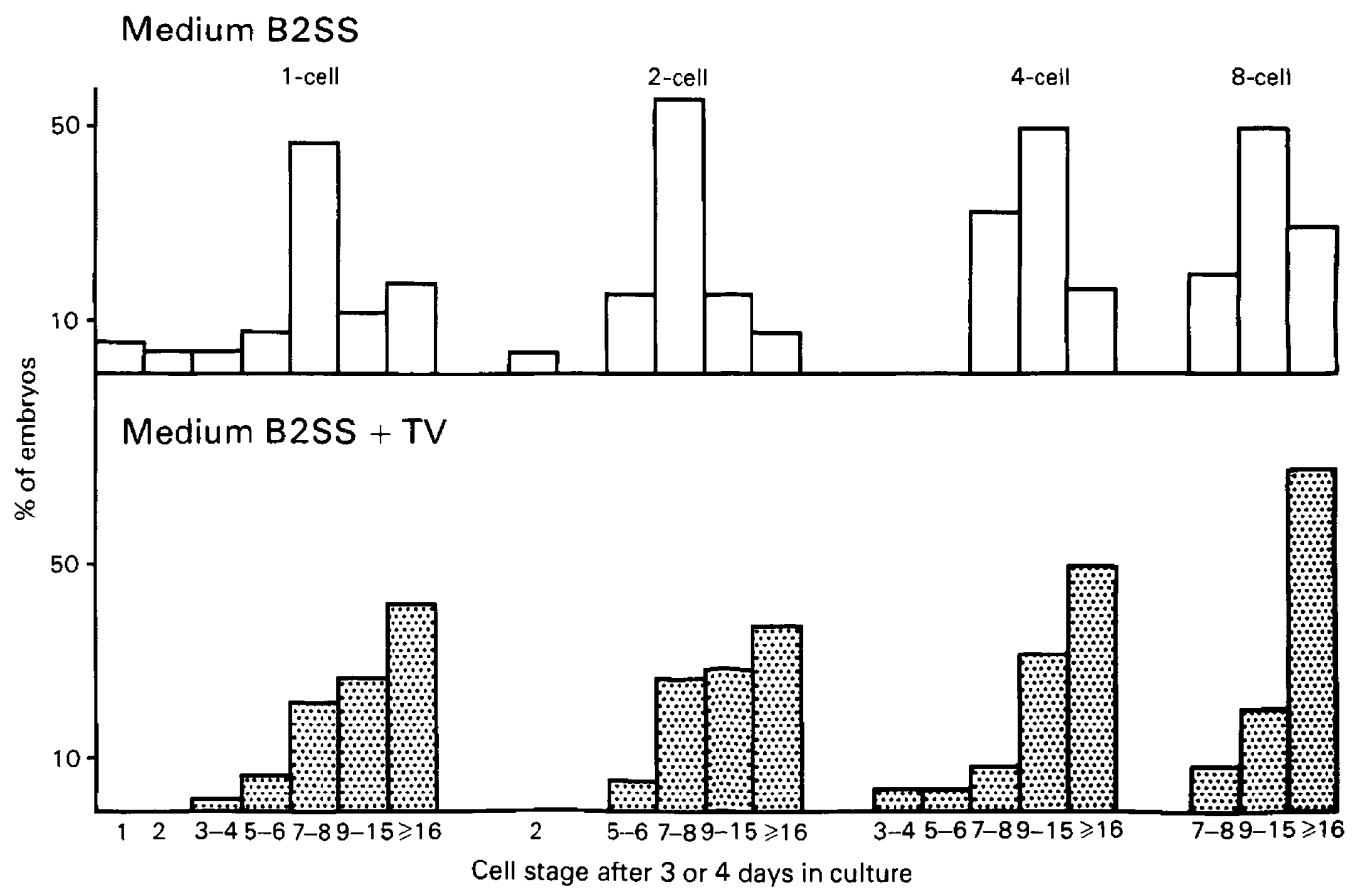

Text-fig. 1. Distribution of cell stages after culture of 1- to 8-cell embryos for 3 or 4 days in Medium B2 containing 15\% fetal calf serum (B2SS) with or without trophoblastic vesicles (TV).

Four embryos ( 3 co-cultured with TV, 1 cultured in Medium B2SS alone) reaching at least the 16-cell stage in culture were sectioned and stained. As shown in P1. 1, Fig. 1, 10 cells were counted in this semi-thin section of an embryo. These cells seemed to be normal and contained numerous clear

\section{PLATE 1}

Fig. 1. Semi-thin section of a morula after culture for 3 days, stained with toluidine blue. Note the abundance of cytoplasmic vesicles (V). L, globules of lipid. $\times 330$.

Figs 2 \& 3. Two bovine blastocysts, one expanded (Fig. 2), recovered after 3 days in co-culture with trophoblastic vesicles and 2 days in utero. T, Trophoblast; ICM, inner cell mass; $B$, blastocoele. $\times 280$.

Figs 4 \& 5. Semi-thin toluidine blue-stained section of the 2 blastocysts shown as intact in Figs $2 \&$ 3. Note mitotic figures (MF) in the trophoblast (T) and in the inner cell mass (ICM). $B$, blastocoele. $\times 580$.

Fig. 6. A normal calf born in November 1983, obtained from a 4-cell embryo cultured for 3 days with trophoblastic vesicles, left for 2 days in utero and stored for 3 months at $-196^{\circ} \mathrm{C}$ before transfer. 


\section{PLATE I}
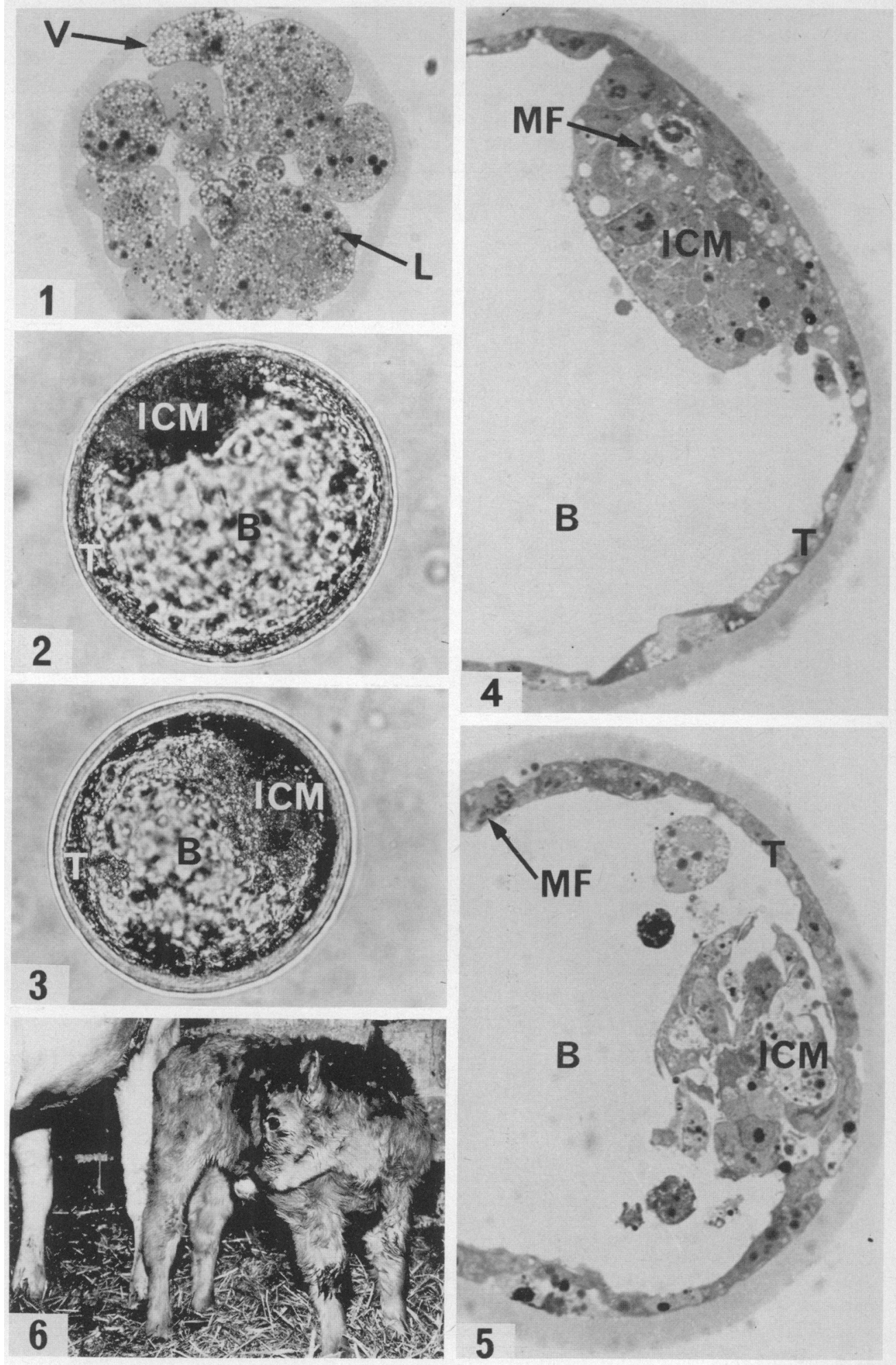

(Facing p. 482) 
cytoplasmic vesicles which were usually uniformly distributed in the cytoplasm. A small number of dark round globules (lipids) were visible in some blastomeres.

\section{Development of cultured embryos in vivo}

After culture in Medium B2SS $(n=18)$ or in Medium B2SS + TV $(n=84), 102$ morulae were transferred to temporary recipients.

Experimental group $(T V)$. Of the 58 embryos recovered from the recipients, $14(24 \%)$ were at the blastocyst stage, most of the remainder being at the compact morula stage. In some morulae, extruded blastomeres were observed which made the qualitative evaluation difficult.

Control group. Of the 10 embryos recovered, $3(30 \%)$ were blastocysts. One blastocyst collapsed just after recovery and did not re-expand. In the remaining 7 embryos, 2 were at the 16-cell stage, 3 were compact morulae and 2 degenerate embryos.

The percentages of morulae developing into blastocysts in vivo were not significantly different between the 2 groups. These blastocysts had developed from all the initial cell stages.

Two co-cultured blastocysts arising from the 8-cell stage were observed before fixation and sectioned for an accurate morphological evaluation (Pl. 1, Figs 2 \& 3). The embryo of larger diameter and with a thinner zona pellucida exhibited an expanded blastocoele and a better defined inner cell mass. Examination of semi-thin sections showed a clear differentiation between a trophoblastic layer and an inner cell mass (Pl. 1, Figs 4 \& 5). The polyhedral inner cell mass cells were in closer contact with each other in one embryo (P1. 1, Fig. 4), while in the other some had entirely lost their contacts and some were isolated in the blastocoele (P1. 1, Fig. 5) and degenerate. Mitotic figures and only a few cytoplasmic vesicles were observed in the trophoblastic and embryonic cells. In the remaining 15 cultured blastocysts recovered, 7 had a defined inner cell mass but showed more degenerate extruded cells than the expanded blastocyst (Pl. 1, Fig. 2), 8 had an appearance similar to the other embryo (Pl. 1, Fig. 3). However, the gross morphological characteristics of these latter blastocysts did not permit determination of whether all embryonic cells were degenerate or whether some were viable.

\section{Final transfer of cultured embryos}

After thawing, both of the deep-frozen blastocysts in the control group and 2 of the 12 in the experimental group were discarded because of degeneration. The remaining 10 embryos were transferred into 10 recipients. Four pregnancies were initiated, but 3 recipients returned to oestrus on Days 26, 40 and 45, respectively; the 4 th recipient delivered at term ( 284 days) a normal male calf (Pl. 1, Fig. 6) weighing $42 \mathrm{~kg}$.

\section{Discussion}

Culture requirements of embryos differ according to their stage of development. The medium successfully used for development of bovine morulae and blastocysts (Renard, du Mesnil du Buisson, Wintenberger-Torrès \& Ménézo, 1976) was not able to support early stage cleavage even after addition of fetal calf serum. Similarly, Kuzan \& Wright (1982) showed that bovine uterine fibroblasts promoted hatching of porcine blastocysts, but did not have a favourable effect on development of porcine morulae.

The present study showed that trophoblastic vesicles promote in-vitro cleavage of early bovine embryos beyond the block stage. The effect was apparent with embryos at the 1-, 2-and 4-cell stages but was greatest for 8-cell embryos. Even in the control group, development of embryos progressed better from the 8-cell than from the 1-, 2- or 4-cell stages. According to Seidel (1977), late 8-cell embryos should be easier to culture than those having just reached the 8-cell stage, but there is no morphological characteristic which distinguishes such embryos. 
Although a greater proportion of embryos developed into morulae after co-culture with trophoblastic vesicles, these embryos did not attain the stage of development expected of embryos of the same age in vivo. Lindner \& Wright (1983) reported that, just after recovery, the majority of Day-5 embryos are at the 20- to 32-cell stage and most Day-6 embryos are at the compact morula stage. After 3 or 4 days in vitro in the present system, the most developed embryos exhibited a delay of about $24 \mathrm{~h}$.

The fine structural characteristics of cultured 16-cell embryos were not obviously different from those of embryos developed in vivo to the same stage (cattle: Brackett, Oh, Evans \& Donawick, 1980; sheep: Calarco \& McLaren, 1976). In particular, cytoplasmic vesicles were found in abundance in both types of embryo. However, deleterious effects were visible after differentiation into blastocysts in the present study. The detrimental effect of culture seems to be exerted specifically on the inner cell mass cells, known to be more sensitive to adverse conditions (Wintenberger-Torrès, 1967). These observations might account for late returns to oestrus, due to the development in utero of trophoblastic tissue only (Martal, 1981; Heyman et al., 1984). Renard et al. (1980) have shown that pregnancy failures also increased after culture of blastocysts for $24 \mathrm{~h}$. On Day 70 the pregnancy rate from non-cultured blastocysts, frozen with the technique used in this study (Renard et al., 1982), was $50 \%$, i.e. about $10 \%$ lower than that obtained with non-frozen embryos. The failure of 3 of the pregnancies in the present study could have been due to damage during deep-freezing (10-40\% of the embryonic cells are damaged; J. P. Renard, personal communication) as well as that due to culture.

This study shows the efficiency of trophoblastic vesicles for culturing embryos beyond the block stage. Therefore some factors involved in the development of early embryos seem to be secreted by bovine trophoblastic vesicles. Two possibilities can be considered: (1) trophoblastic vesicles provide some metabolic compounds (such as lipids) normally present in the genital tract and required for early embryo cleavage; and (2) a cleavage-inducing or -regulating signal is acquired by embryos during their transit through the oviduct. This signal could persist in the embryos, but at a lower level, until the elongating blastocyst stage.

This or these substance(s) whose biochemical nature(s) are unknown are most probably secreted by the trophoblastic cells because of their abundance and their high secretory activity compared to the endodermic cells (Heyman et al., 1984). These substances do not seem to be labile; in preliminary experiments in which early embryos were cultured in Medium B2, which had previously supported development of trophoblastic vesicles for $24 \mathrm{~h}$, we obtained an effect that was intermediate between those obtained by culture in medium alone and by co-culture with trophoblastic vesicles. Further experiments are required to identify the compound(s) normally present in the genital tract and released by the bovine trophoblastic vesicles in vitro which facilitate cleavage of embryos beyond the block stage.

We thank P. Chesné and V. Garnier for technical assistance; R. Scandolo and C. Slagmulder for photographic assistance; A. Bouroche for help in English translation; and V. du Créhu for typing the manuscript.

\section{References}

Brackett, B.G., Oh, Y.K., Evans, J.F. \& Donawick, W.I. (1980) Fertilization and early development of cow ova. Biol. Reprod. 23, 189-205.

Calarco, P.G. \& McLaren, A. (1976) Ultrastructural observations of preimplantation stages of sheep. $J$. Embryol. exp. Morph. 36, 609-622.

Camous, S., Heyman, Y. \& Ménézo, Y. (1984) In vitro culture of early bovine embryos with trophoblastic vesicles: cleavage through the block stage followed by pregnancy after transfer. Theriogenology 21, 226, Abstr.

Elsden, R.P., Nelson, L.D. \& Seidel, G.E., Jr (1978) Superovulating cows with follicle stimulating hormone and pregnant mare's serum gonadotropin. Theriogenology 9, 17-26.

Heyman, Y., Camous, S., Fèvre, J., Méziou, W. \& Martal, 
J. (1984) Maintenance of the corpus luteum after uterine transfer of trophoblastic vesicles to cyclic cows and ewes. J. Reprod. Fert. 70, 533-540.

Kuzan, F.K. \& Wright, R.W., Jr (1982) Blastocyst expansion, hatching, and attachment of porcine embryos cocultured with bovine fibroblasts in vitro. Anim. Reprod. Sci. 5, 57-63.

Lindner, G.M. \& Wright, R.W., Jr (1983) Bovine embryo morphology and evaluation. Theriogenology 20, 407416.

Martal, J. (1981) Régulation endocrinienne du corps jaune. In L'Utérus de la Vache, pp. 79-100. Eds A. Constantin \& E. Meissonnier. E.N.V.A. MaisonsAlfort.

Ménézo, Y. (1976) Milieu synthétique pour la survie et la maturation des gamètes et pour la culture de l'oeuf fécondé. C. r. hebd. Séanc. Acad. Sci. Paris D 282, 1967-1970.

Muggleton-Harris, A.L., Whittingham, D.G. \& Wilson, L. (1982) Cytoplasmic control of preimplantation development in vitro in the mouse. Nature, Lond. 299, 460-462.

Ozil, J.P., Heyman, Y. \& Cassou, R. (1980) Embryo recovery in young heifers and large old donor cows. Proc. 9th Int. Congr. Anim. Reprod. \& A.I., Madrid, pp. 581-584.

Renard, J.P., du Mesnil du Buisson, F., WintenbergerTorrès, S. \& Ménézo, Y. (1976) In vitro culture of cow embryos from Day 6 and Day 7. In Egg Transfer in Cattle, pp. 159-164. Ed. L. E. A. Rowson. Commission of the European Communities, Luxembourg.

Renard, J.P., Heyman, Y. \& du Mesnil du Buisson, F. (1977) Unilateral and bilateral cervical transfer of bovine embryos at the blastocyst stage. Theriogenology 7, 189-192.

Renard, J.P., Heyman, Y. \& Ozil, J.P. (1980) Importance of gestation losses after non-surgical transfer of cultured and non-cultured bovine blastocysts. Vet. Rec. 107, 152-153.

Renard, J.P., Heyman, Y. \& Ozil, J.P. (1982) Congélation de l'embryon bovin: une nouvelle méthode de décongélation pour le transfert cervical d'embryons conditionnés une seule fois en paillette. Annls Méd. Vét. 126, 23-32.

Seidel, G.E., Jr (1977) Short maintenance and culture of embryos. In Embryo Transfer in Farm Animals: A Review of Techniques and Applications, pp. 20-24. Ed. K. J. Betteridge. Canada Dept. of Agriculture, Monograph 16.

Tervitt, H.R., Whittingham, D.G. \& Rowson, L.E.A. (1972) Successful culture in vitro of sheep and cattle ova. J. Reprod. Fert. 30, 493-497.

Thibault, C. (1966) La culture in vitro de l'oeuf de vache. Annls Biol. anim. Biochim. Biophys. 6, 159-164.

Whittingham, D.G. \& Biggers, J.D. (1967) Fallopian tube and early cleavage in the mouse. Nature, Lond. 213, 942-943.

Wintenberger-Torrès, S. (1967) Etude expérimentale de la migration tubaire des oeufs et de leur segmentation chez la Brebis. D.Sc. thesis, Faculty of Science, Paris.

Wright, R.W., Jr \& Bondioli, K.R. (1981) Aspects of in vitro fertilization and embryo culture in domestic animals. J. Anim. Sci. 53, 702-729.

Received 15 March 1984 